\title{
Statyba
}

\section{SHRINKAGE INFLUENCE ON STRESS-STRAIN STATE OF COMPOSITE MASONRY MEMBERS}

\section{G. Marčiukaitis}

To cite this article: G. Marčiukaitis (2001) SHRINKAGE INFLUENCE ON STRESS-

STRAIN STATE OF COMPOSITE MASONRY MEMBERS, Statyba, 7:3, 177-183, DOI:

10.1080/13921525.2001.10531721

To link to this article: https://doi.org/10.1080/13921525.2001.10531721

曲 Published online: 30 Jul 2012.

Submit your article to this journal

山 Article views: 99 


\section{SUSITRAUKIMO DEFORMACIJU ITTAKA KOMPLEKSINIŲ MŪRO ELEMENTU ITEMPIŲ IR DEFORMACIJŲ BÜVIUI}

\section{G. Marčiukaitis}

\section{Vilniaus Gedimino technikos universitetas}

\section{Ivadas}

Kompleksiniais mūriniais yra vadinami mūriniai, sudaryti iš mūro ir gelžbetonio arba betono.

Gelžbetonis gali būti išdèstomas kompleksinio elemento skerspjūvio viduje, išoreje arba, jeigu mūrinys yra iš tuštymètų blokelių, - jų tuštumose (1 pav.). Kompleksiniai müriniai vis plačiau taikomi ịvairiu tipų konstrukcijose. Tam yra gaminami specialūs keraminiai ir betoniniai blokeliai, $\mathfrak{i}$ kurių tuštumas arba ipjovas yra dedama armatūra ir likusi erdve užbetonuojama. Pagal veikiančias normas tokios konstrukcijos yra skaičiuojamos skerspjūvių redukavimo metodu. Tačiau pagal ši metodą neivertinamas deformacijų suderinamumas. Ivairių literatūros duomenų [1-4] ir projektavimo normų [5-7] nurodymu palyginimas ir analizé rodo, kad mūro deformatyvumas labai skiriasi nuo betono ir gelžbetonio, tačiau nenurodoma, kaip tai ivvertinti atliekant skaičiavimus. Antra vertus, praktiškai neimanoma pasiekti, kad būtų suderintos, t. y. vienodos tokios svarbios šių dviejų skirtingu medžiagu deformacinès savybès, kaip susitraukimas bei valkšnumas, kurios turi didelę itaką kompleksinio ir sluoksniuotojo mūrinio pradiniam ittempimų ir deformacijų būviui ir bendram sluoksnių darbui. Reikia pažymèti, kad mūrinių ir kartu kompleksinių konstrukcijų gyvavimo stadijų tyrimai mūsų šalyje jau beveik neatliekami. Paskutinis didesnis darbas, kuriame yra pateikiami kai kurie įvairių šalių autorių atlikti tyrimai, yra prof. A. Rozenbliumo darbai [3]. Juose nurodoma, kad egzistuoja skirtingas kompleksinio mūro komponentụ (mūro ir gelžbetonio) deformavimasis (susitraukimas, ribinès gniuždymo deformacijos), tačiau nèra duomenu, kaip analitiškai ir praktiškai juos suderinti kompleksiniame mūrinyje. Tai rodo, kad nebuvo atliekami išsamesni nei teoriniai, nei eksperimentiniai tyrimai su ivairių tipụ kompleksiniais mūriniais.
Nebuvo skelbta panašių tyrimų rezultatų ir kitose šalyse, nors eksperimentais įrodyta, kad nuo mūro dirbiniu ir jų savybiu priklauso mūro traukimasis ir pleišèjimas $[8,9]$.

a

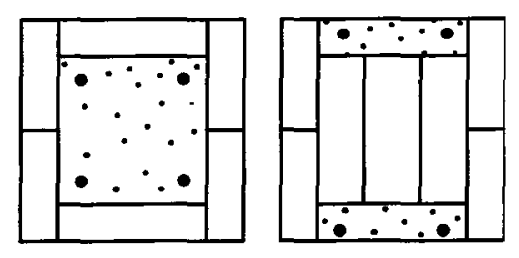
b

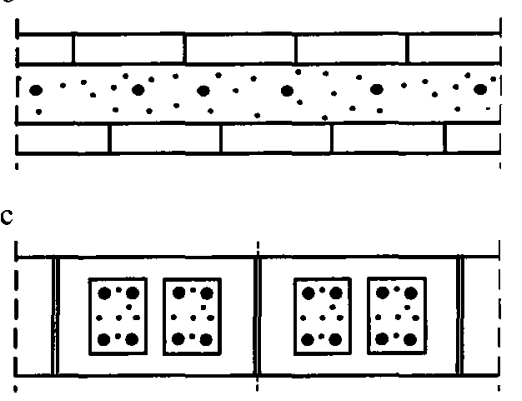

1 pav. Kompleksinių mūrinių schemos: a - kolonų, kai gelžbetonis skerspjūvio viduje ir išorèje; b - gelžbetonis mūro sienц viduje; c - gelžbetonis blokeliu tuštumose

Fig 1. Composite masonry: a - columns with reinforced concrete inside and outside the cross-section; $b$ - reinforced concrete inside of masonry walls; $\mathrm{c}$ - reinforced concrete inside the openings of blocks

Praktika rodo, kad skirtingos müro ir gelžbetonio (betono) susitraukimo deformacijos šiose medžiagose sukelia pradinius itempimus, kurie turi itakos atskiru sluoksnių ir viso skerspjūvio bendram darbui. Dèl to sumažèja sukibimas tarp müro ir gelžbetonio ar betono sluoksnių, mūro sluoksnyje (sienose) gali atsirasti net plyšių [4, 8] arba jis gali pirma laiko išklupti. Todèl, norint tiksliai juertinti tokių kompleksinių konstrukcijų būvi jas apkrovus, reikia žinoti pradini ittempimų ir 
deformaciju būvi esant skirtingam medžiagu ir sluoksnių iš jų susitraukimui. Tačiau tokių tyrimų beveik nèra. Be to, trūksta duomenų apie mūro ir gelžbetonio susitraukimo deformacijas bei ju pobūdi, kai jie vienas su kitu yra sukibę.

\section{Mūro ir gelžbetonio laisvųjų susitraukimo defor- macijų nustatymas ir palyginimas}

Mūro ir betono bei gelžbetonio susitraukimas priklauso nuo daugelio veiksnių, kuriuos sudètinga tiksliai ịvertinti. Tačiau, kaip rodo daugelio jvairių autorių ir mūsų atlikti tyrimai $[1,2,4,8]$, mūro susitraukimo deformacijoms daugiausia įtakos turi mūrui naudojamų dirbinių medžiagos tipas (keramika, silikatas, betonas ir pan.), jų matmenys, mūro siūlių skiedinio tipas (cementinis, kalkių, mišrus) bei siūlių storis. Ivairių duomenu analizè rodo, kad mūro susitraukimo dydžiui ir pobūdžiui daugiausia įtakos turi drèkimo procesai, vykstantys tarp vandens turinčio skiedinio ir mūro dirbinio, kurio pradinis drègnis būna daug mažesnis. Apskritai mūro susitraukimas - tai siūlès skiedinio ir mūro dirbinio susitraukimas. Antra vertus, siūlès skiedinio susitraukimas susideda iš jo nusèdimo kietėjimo pradžioje, iš susitraukimo, vykstant fiziniams ir cheminiams procesams kietejančiame skiedinyje, ir drègminio susitraukimo arba išsiplettimo. Skiedinio susitraukimą skersine kryptimi varžo daug mažiau besitraukiantys mūro dirbiniai. Tai sukelia šlyties įtempimus dirbinio ir siūlès kontakto plokštumoje. Tačiau mūro vertikaliam susitraukimui tai neturi daug itakos. Kaip ir betonui [10-14], mūro susitraukimui, esant to paties tipo dirbiniams, itakos turi skiedinio drègmès netekimas. Tačiau laisvasis vanduo (drègmè) iš skiedinio tuoj po jo padejjimo i siūlę yra mūro dirbinių sugeriamas ir tuo pagreitinamas susitraukimas. Tai yra pagrindinis skirtumas tarp laisvo skiedinio susitraukimo pobūdžio, kuris panašus $\mathfrak{i}$ betono susitraukimą, ir skiedinio, esančio tarp mūro dirbinių (siūlèse). Vandens ištraukimas iš skiedinio ir kartu skiedinio susitraukimas priklauso nuo skiedinio tipo, t. y. jo sugebėjimo sulaikyti drègmę (vandeni) ir mūro dirbiniu tipo, jų struktūros, pradinio drègnio ir pan. Antra vertus, skiedinys, perduodamas savo drègni dirbiniams, didina jų drègni ir jie pradeda plèstis. Vadinasi, galima laikyti, kad, kiek skiedinys netekdamas drègnio susitraukia, tiek dèl papildomos drègmès iš skiedinio mūro dirbiniai santykinai išsiplečia. Tai patvirtina daugelio autoriu duomenų analizè $[2,15]$. Irodyta, kad betono ir kartu skiedinio susitraukimas tiesiogiai priklauso nuo aplinkos drègnio ir taip pat vidinio drègnio pokyčio, t. y.

$$
\varepsilon_{s h}=\beta_{s h}\left(u_{0}-u_{1}\right),
$$

$u_{0}$ ir $u_{1}$ - pradinis santykinis drègnis ir santykinis drègnis po tam tikro laiko; $\beta_{s h}$ - koeficientas, priklausantis nuo viso atitinkamo elemento (siūlès dirbinio) $V$ tūrio ir jo kietosios fazès $V_{1}$ tūrio, gali būti nustatomas pagal tokią formulę [16]:

$$
\beta_{s h}=\frac{1}{3} \frac{V}{V_{1}}
$$

$\beta_{s h}$ koeficientas yra vadinamas ir linijinio susitraukimo koeficientu. Tyrimai ir jvairių autorių duomenų analizè parodè, kad šis koeficientas cementiniam skiediniui gali būti imamas kaip ir betonui $0,03 \frac{\mathrm{mm} / \mathrm{mm}}{\mathrm{g} / \mathrm{g}}$, o mišriam (cemento ir kalkiụ) $0,024 \frac{\mathrm{mm} / \mathrm{mm}}{\mathrm{g} / \mathrm{g}}$, nes šis skiedinys labai sulaiko vandenị. Tyrimai rodo, kad mūrui naudojamų medžiagų susitraukimo ir išsiplètimo pobūdis nèra vienodas, tačiau ribinès absoliutinès ju reikšmès beveik vienodos. Vadinasi, pasinaudojus kompozitụ teorijos mišinio dèsniu, galima užrašyti:

$$
\varepsilon_{s h, m}(t)=\delta_{m o r} \varepsilon_{s h, m o r}(t)+\delta_{u n} \varepsilon_{s h, u n}(t),
$$

$\varepsilon_{s h, m}(t)$ - mūro vertikaliosios susitraukimo deformacijos bet kuriam $t$ laikui; $\varepsilon_{s h, m o r}(t), \varepsilon_{s h, u n}(t)$ - siūlès skiedinio ir mūro ir dirbiniu susitraukimo deformacijos tuo pačiu metu; $\delta_{m o r}$ - santykiniai siūlès $\left(\frac{h_{j}}{h_{j}+h_{u n}}\right)$ ir mūro dirbinio (plytos, blokelio) aukščiai $\left(\frac{h_{u n}}{h_{j}+h_{u n}}\right) \cdot \delta_{m o r}+\delta_{u n}=1$.

(3) formulès analizè rodo, kad, žinant mūro eilių aukščius (ir siūlès storị) ir medžiagu susitraukimo deformacijas, galima apskaičiuoti mūro vertikaliąsias susitraukimo deformacijas.

Tačiau literatūroje mažai sutinkama duomenų apie mūrui naudojamų medžiagu susitraukimo deformacijas. Remiantis tyrimų rezultatais pagal (3) formulę [2] buvo apskaičiuotos mūro susitraukimo deformacijos. Palyginus šiuos duomenis, matyti, kad mūro deformacijos, apskaičiuotos pagal (3) formulę, duoda pakankamai tikslius rezultatus (2 pav.). 


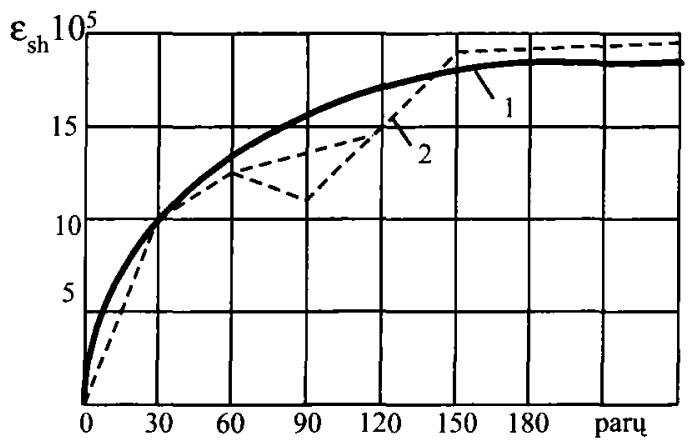

2 pav. Mūro susitraukimo deformacijos: 1 - apskaičiuotos pagal (3) formulę; 2 - eksperimentinès [2], apskaičiuojant pagal (1) formulę, medžiagu $\varepsilon_{s h}(t)$ imtos iš [2]

Fig 2. Masonry shrinkage deformations: 1 - calculated according to eq. (3); 2 - experimental. Calculated according to eq. (1), where $\varepsilon_{s h}(t)$ is taken from [2]

Kaip rodo mūsų atlikta analizè [4], mūro susitraukimo deformacijų kitimą per laiką galima aprašyti tokia priklausomybe:

$$
\varepsilon_{s h, m}(t)=\varepsilon_{s h, 0}\left(1-e^{-b t}\right)
$$

$\varepsilon_{s h, 0}$ - ribinès susitraukimo deformacijos; $t$ - laikas; $b$ - koeficientas, priklausantis nuo mūro dirbiniu; praktiškai skaičiuojant galima imti tokias jo reikšmes:

- keraminiụ plytu mūrui $-0,035$;

- keraminiu blokeliu - 0,040;

- silikatiniu plytu ir blokeliu mūrui - 0,020;

- betoninių blokelių mūrui - 0,025.

Ribinès mūro susitraukimo deformacijos daugeliui mūru yra beveik vienodos ir lygios $\varepsilon_{s h, 0}=20 \cdot 10^{-5}$, išskyrus mūrui iš keraminiu dirbinių, kuriam jos gali būti ir priešingo ženklo, t. y. nesitraukia, o plečiasi dèl gaunamos drègmès $[1,2,7]$.

Iš 2 paveikslo matyti, kad mūro susitraukimo deformacijos labiau dideja pirmosiomis dienomis ir per 30 parų pasiekia beveik pusę ribinių deformacijų dydžio. Analizé rodo [4, 12, 15], kad (4) formule galima aprašyti ir betono susitraukimo deformaciju kitimo pobūdị. Tačiau jo ribinès susitraukimo deformacijos $\varepsilon_{s h, 0}$ ir koeficientas $b$ yra kitokie negu mūro. Literatūroje pateikti ju duomenys yra labiau apibendrinti ir pagristi. Tačiau, kaip rodo tyrimai ir sukauptu duomenu analizė [10-12], ribinès betono susitraukimo deformacijos ir ju pobūdis taip pat priklauso nuo daugelio veiksniu. Todèl $b$ koeficiento (4) formulèje nustatymas turi būti pagristas eksperimentais. Euronormos [11, 17] rekomenduoja betono susitraukimo ribines deformacijas imti priklausomai nuo elemento dydžio (skerspjūvio ploto $A_{c}$ ir perimetro $u$ santykio) ir aplinkos drégmés. Kompleksiniuose mūriniuose $2 A_{c} / u=h \leq 150$, kai aplinkos santykinis drègnis $50 \%-\varepsilon_{s h, 0}=60 \cdot 10^{-5}$, kai $80 \%$ ir daugiau $-\varepsilon_{s h}=33 \cdot 10^{6}$.

Tačiau kompleksiniame mūrinyje betono sluoksnis yra aplinkoje, kurios santykinis drègnis dažniausiai yra ne didesnis kaip 50\% (mūro dirbiniai - plytos, blokeliai ir pan.). Mūras traukia iš betono laisvaji vandeni ir tuo padidina jo susitraukimo deformacijas.

Analizè parodè, kad betono sluoksnio susitraukimo deformacijos yra 3-4 kartus didesnès už mūro susitraukimo deformacijas. Kadangi technologiškai mūrijimas ir betonavimas vyksta beveik vienu metu, mūro dirbiniai (plytos, blokeliai ir pan.) traukia drègme iš betono, mūro susitraukimo deformacijos sumažeja, o betono - padidèja.

Neturint $b$ koeficiento (4) formulëje reikšmiu, betono susitraukimo kitimą laikui bègant galima apskaičiuoti pagal formulę, kuri gauta remiantis euronormomis $[7,15]$ :

$$
\varepsilon_{s h, c}(t)=\varepsilon_{s h, 0}\left[\frac{t / t_{1}}{350\left(h / h_{0}\right)^{2}+t / t_{1}}\right]^{0,5},
$$

$t$ - susitraukimo deformaciju vystymosi laikas dienomis; $t_{1}-1$ diena; $h=\frac{2 A_{\mathcal{C}}}{u} ; h_{0}=100 \mathrm{~mm}$.

Tačiau daugeliu atveju kompleksinių mūrinių betono komponentas yra armuojamas. Armatūra varžo jo laisvaji susitraukimą ir kartu sumažina bendrąsias jo susitraukimo deformacijas (3 pav.).

a
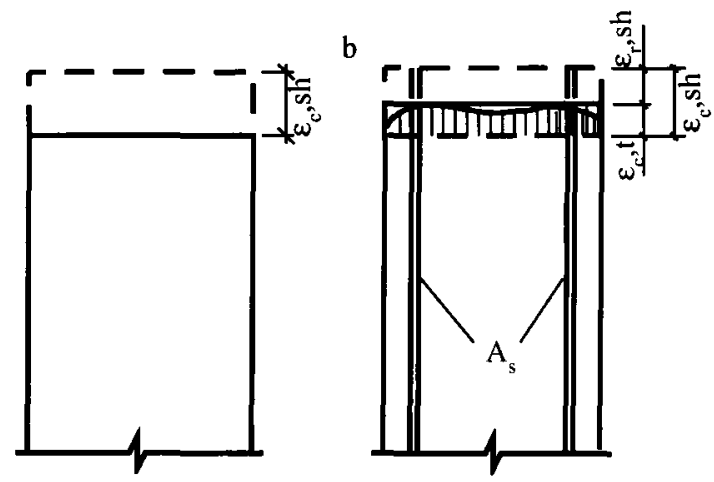

3 pav. Nearmuotojo (a) ir armuotojo (b) betono susitraukimo schemos, naudojamos daugelio autoriu tyrimuose

Fig 3. Shrinkage diagrams of non-reinforced (a) and reinforced (b) concrete used in experiments by most authors 
Kaip matyti iš 3 paveikslo schemų, armuotojo betono susitraukimo deformacijos $\varepsilon_{r, s h}$ yra mažesnès už nearmuotojo $\varepsilon_{c, s h}$. Armuotame betone atsiranda tempimo deformacijos $\varepsilon_{c, t}$. Taigi armuotojo betono susitraukimo deformacijos analogiškai bus:

$$
\varepsilon_{r, s h}=\varepsilon_{c, s h}-\varepsilon_{c, t} .
$$

Laikant, kad armuotojo betono susitraukimo deformacijos lygios armatūros gniuždymo nuo betono suspaudimo tampriosioms deformacijoms $\left(\varepsilon_{r, s h}=\frac{\sigma_{s}}{E_{s}}=\frac{\sigma_{c, t}}{\mu E_{s}}\right.$; $\left.\varepsilon_{c, t}=\frac{\sigma_{c, t}}{E_{c, t}}\right)$ ir i (6) formule irašius deformaciju reikšmes bei atlikus atitinkamus pertvarkymus, gaunama:

$$
\varepsilon_{r, s h}=\varepsilon_{c, s h}\left(\frac{v_{t} E_{c}}{v_{t} E_{c}+\mu E_{s}}\right) .
$$

$\sigma_{s}$ - gniuždymo ịtempiai armatūroje; $\sigma_{c, t}-$ tempimo itempiai betone; $\mu$ - armavimo koeficientas $\mu=A / A_{s}$; $E_{s}$ - armatūros deformaciju modulis; $v_{t}$ - betono tampriai plastiniu deformaciju koeficientas tempiant (jis kinta nuo 1 iki 0,15 , praktiškai galima laikyti, kad jis lygus 0,5 )

Ši formulè analogiška daugelio kitu autoriu, nagrinèjančiu armuotojo betono susitraukimo ịtaką ịtempimu būviui, formulèms.

Esant vidiniams itempiams betone ir armatūroje, pasireiškia valkšnumo deformacijos, kurios turi itakos armuotojo betono susitraukimui. $\mathrm{Be}$ to, kinta betono stipris ir deformaciju modulis. Tačiau, kaip rodo tyrimai [12], betono deformacijų modulio padidejimas iki dvieju kartu turi nedaug itakos armuotojo betono susitraukimui, ivertinant jo valkšnumą. Apskritai apskaičiuojant armuotojo betono susitraukimo deformacijas daugelis normatyvinių dokumentų valkšnumo itakos neivertina [12]. Daugiausia itakos turi armatūros kiekis, t. y. armavimo koeficientas $\mu$, taip pat betono ir armatūros deformaciju moduliu santykis $\frac{E_{s}}{E_{c}}$ (4 pav.). Kai $\mu=0,01$, susitraukimo deformacijos vidutiniškai sumažeja $20 \%$. Beveik perpus sumažèja, kai $\mu=0,3$. Vadinasi, galima parinkti tokią betono klasę ir jai atitinkantį tamprumo moduli arba armavimo koeficienta, kad mūro ir gelžbetonio susitraukimo deformacijos būtu vienodos arba artimos.

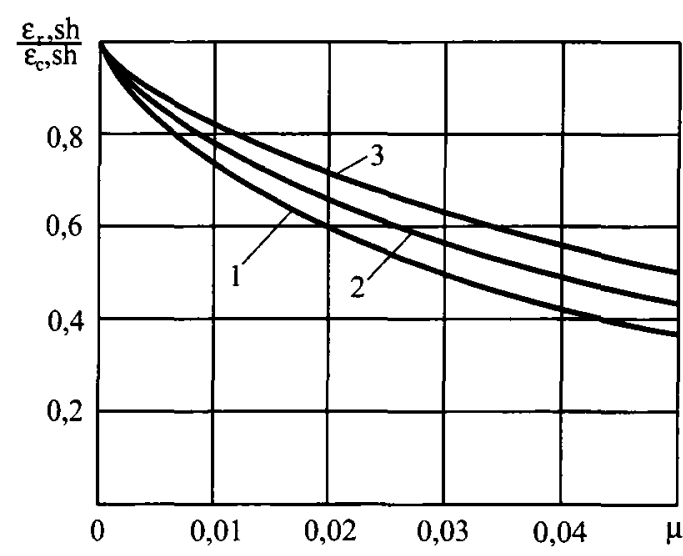

4 pav. Armavimo $\mu$ koeficiento ir deformaciju moduliu $E_{s} / E_{c}$ itaka betono susitraukimui: $1-E_{s} / E_{c}=10$; $2-8 ; 3-6$

Fig 4. Reinforced ratio $(\mu)$ and modulus ratio $E_{s} / E_{c}$ influence on shrinkage of concrete: $1-E_{s} / E_{c}=10$; $2-8 ; 3-6$

\section{Itempimų ir deformacijų būviai dèl skirtingo su- sitraukimo ir jų apskaičiavimas}

Kaip buvo nurodyta, mūras ir gelžbetonis arba betonas traukiasi skirtingai. Todèl viename iš komponentu gali atsirasti gniuždymo, kitame tempimo įtempiai. Tempimo itempiai atsiras komponente, kurio susitraukimo deformacijos yra didesnès, panašiai kaip ir pavaizduotos 3 paveikslo schemoje. Vadinasi, galimi trys itempimų būviai:

1 - jeigu mūro ir gelžbetonio susitraukimo deformacijos yra vienodos, itempimų kompleksiniame mūre dèl susitraukimo nebus;

2 - jeigu mūro susitraukimo deformacijos yra mažesnès negu betono arba gelžbetonio, tai mūre atsiras gniuždymo įtempimai, o betone (arba gelžbetonyje) tempimo;

3 - jeigu mūro susitraukimo deformacijos yra didesnès, mũre atsiras tempimo îtempimai, o betone arba gelžbetonyje - gniuždymo.

Itempius sluoksniuose galima apskaičiuoti iš pusiausvyros sąlygos, t. y. iš susitraukimo ittempiu sluoksniuose tarpusavio pusiausvyros sąlygos.

Kai yra ryšys tarp mūro ir betono ar gelžbetonio sluoksnių, jie deformuojasi vienodai $[18,19]$ :

$$
\varepsilon_{c}(t)=\varepsilon_{r, c}(t)=\varepsilon_{m}(t)
$$

arba

$$
\varepsilon_{r, c}(t)-\varepsilon_{m}(t)=0 .
$$


Itempių ir dèl jų atsiradusių irąžu pusiausvyros sąlyga bus:

$$
\varepsilon_{1}(t) E_{1} A_{1}-\left[\varepsilon_{2}(t)-\varepsilon_{1}(t)\right] E_{2} A_{2}=0 .
$$

$\varepsilon_{1}(t) E_{1} A_{1}$ - mažiau besitraukiančio komponento gniuždymo deformacijos modulis ir skerspjūvio plotas; $\varepsilon_{2}(t) ; E_{2} ; A_{2}$ - daugiau besitraukiančio komponento susitraukimo deformacijos, jo deformaciju modulis ir plotas.

Iš (10) lygties gauname:

$$
\varepsilon_{1}(t)=\varepsilon_{2}(t) \frac{E_{2} A_{2}}{E_{1} A_{1}+E_{2} A_{2}} .
$$

Mažiau besitraukiančiame sluoksnyje atsiradę gniuždymo ịtempiai praktiškai neviršija sąlyginès tamprumo ribos. Tuomet iš (11) formulès gauname:

$$
\sigma_{1}(t)=\varepsilon_{2}(t) E_{1} \frac{E_{2} A_{2}}{E_{1} A_{1}+E_{2} A_{2}} .
$$

Vidutiniai tempimo itempiai labiau besitraukiančiame sluoksnyje bus:

$$
\sigma_{2}(t)=\varepsilon_{2}(t) E_{1} \frac{A_{1}}{A_{2}} \frac{E_{2} A_{2}}{E_{1} A_{1}+E_{2} A_{2}} .
$$

Apskaičiuojant itempius pagal (12) ir (13) formules reikia žinoti ne tik vieno iš sluoksniu susitraukimo deformacijas, bet ir jų tamprumo modulius. Reikia pažymèti, kad susitraukimas vyksta nuo pat mūrijimo pradžios, tačiau, kol nèra visiško sukibimo, visos medžiagos (mūro skiedinys ir betonas) yra takios (plastiškos), ju tamprumo modulio kitimo ir apskritai itempių atsiradimo kitimo per pirmąsias dienas praktiškai galima neįvertinti. Toliau analizuojant galima laikyti, kad mūro ir gelžbetonio tamprumo moduliai yra pastovīs. Kaip žinoma, normatyviniuose dokumentuose ir apskritai literatūroje gelžbetonio tamprumo ir deformacijų moduliai nepateikiami. Todèl šiuos gelžbetonio modulius $E_{r, c}$ galima apskaičiuoti, žinant betono $\left(E_{c}\right)$ ir armatūros $\left(E_{s}\right)$ moduliụ reikšmes ir taikant kompozitu teorija. Kai łrąžı veikimo kryptis sutampa su armatūros išdèstymo kryptimi, tai

$$
E_{r, c}=E_{s} \frac{A_{s}}{A_{r, c}}+E_{c} \frac{A_{\mathcal{c}}}{A_{r, c}},
$$

$A_{s}, A_{c}$ ir $A_{r, c}-$ išilginès armatūros betono ir viso gelžbetoninio elemento skerspjūvio plotai.

Mūro tamprumo ir deformacijụ moduliai priklauso nuo mūro tipo (plytų, blokelių, jų matmenų, skiedinio stiprumo ir kt.), tačiau pagal mūsų šalyje galiojančias normas jis yra nustatomas skirtingai. Pagal SNirT $[5,6]$ :

$$
E_{m}=\alpha R_{m},
$$

$\alpha$ - mūro tamprumo charakteristika, kuri priklauso nuo mūro tipo (pateikiama lentelèse).

Pagal euronormas [7]

$$
E_{m}=k \cdot R_{m},
$$

$R_{m}=f_{k}-$ mūro stipris; $k$ - koeficientas, priklausantis nuo mūro dirbiniu tipo. Jeigu dirbiniai (plytos, blokeliai) yra silikatiniai arba autoklavinio kietėjimo betoniniai, $k=650$, kitu tipц $k=1000$. Praktiškai tai beveik atitinka ir pagal $[5,6]$ nustatytas reikšmes, kai skiedinio markè ne mažesnè kaip 10.

Žinant komponentu susitraukimo deformaciju kitimo laikui bėgant reikšmes, nustatomas pagal (4) arba (5) formules, itempiai komponentuose (sluoksniuose) yra apskaičiuojami pagal (12) ir (13) formules. Šios formulès nusako bendrajị itempimų būvio pobūdį. Jụ absoliutinès reikšmès kinta dèl ịtempių persiskirstymo.

\section{Itempimų ir deformacijų pasiskirstymo sluoksniuo- se analizè}

Iš (12)-(14) formuliụ analizès matyti, kad jose pateiktos atitinkamo komponento (sluoksnio) vidutinès deformacijų ir itempimų reikšmès. Tačiau vienam sluoksniui traukiantis daugiau, irąžos nuo jo kitam persiduoda per kontakto plokštuma, vadinasi, ne iš karto $\mathfrak{i}$ visą atitinkamo sluoksnio skerspjūvio plotą. Jeigu imamas simetrinis skerspjūvio elementas ( 1 pav. b, c), tai labiau besitraukiantis vidurinis sluoksnis necentriškai gniuždys išorinius sluoksnius (5 pav.)

Jèga, kuri atsiranda nuo labiau besitraukiančio vidurinio sluoksnio, bus:

$$
N=A_{2} \sigma_{2}(t),
$$

$\sigma_{2}(t)$ - vidutiniai įtempimai, apskaičiuojami pagal (13) formulę.

Kadangi $N$ simetriškai gniuždomi abu sluoksniai ( 5 pav. a pavaizduota jos reakcija), tai vienam sluoksniui tenka $0,5 N$. Tačiau ji gaunama pridèta necentriškai lietimosi plokštumoje. Ties išorinio sluoksnio centru pridèję dvi viena kitai priešingas jègas, lygias $0,5 \mathrm{~N}$, gauname tipišką necentrini gniuždymą ( 5 pav. c). Išori- 


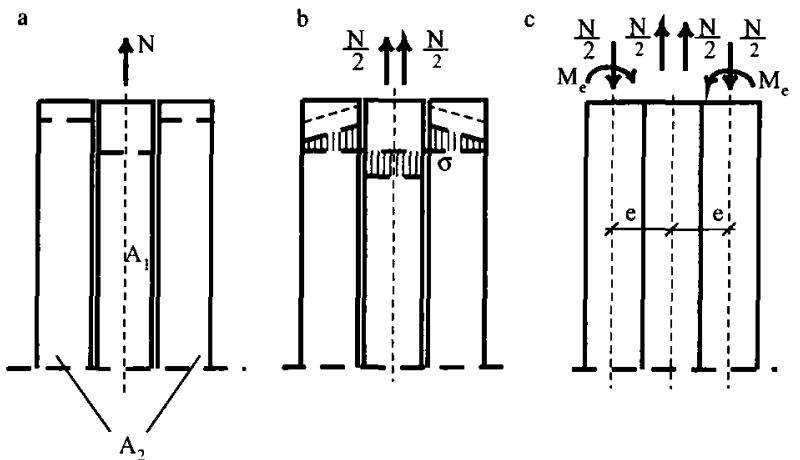

5 pav. Deformacijų ir irąž̆ pasiskirstymo schemos: a laisvas sluoksnių deformavimasis; b - itempių ir irą̌ž pasiskirstymas; $c$ - įražos sluoksniuose

Fig 5. Diagrams of stress-strain distribution: a - free shrinkage strain of layers; $b$ - distribution of stresses and strain; $c$ - strains in layers

ni sluoksni veikia ašinè jèga $0,5 \mathrm{~N}$ ir lenkimo momentas:

$$
M_{e}=0,5 N \cdot e .
$$

Kadangi mūras daugeliui darbo stadiju yra skaičiuojamas kaip tamprusis kūnas, i̇tempimu pasiskirstymas išoriniuose sluoksniuose apskaičiuojamas pagal žinomą medžiagu atsparumo formulę:

$$
\sigma=\frac{N}{A_{1}} \pm \frac{M_{e} \cdot y}{I},
$$

$y$ - atstumas nuo sluoksnio svorio centro iki skaičiuojamojo taško; $I$ - sluoksnio skerspjūvio inercijos momentas.

Iš 6 pav. pateiktų kreivių matyti, kad atitinkamai parenkant kompleksinio skerspjūvio atskiru sluoksniu matmenis ir ju medžiagu tamprumo moduliu santykius galima gauti tokio skerspjūvio konstrukcija, kurio sluoksniuose bus mažiausi tempimo (labiau besitraukiančiame) ir gniuždymo (mažiau besitraukiančiame) ịtempimai.

Daugeliu atveju mūro stiprumas gniuždymui kompleksiniuose elementuose dèl didesnių ribiniu susispaudimo deformaciju nèra visiškai išnaudojamas [20]. Todèl pateikta metodika leidžia reguliuoti ši išnaudojimo laipsni, ivertinant itempius dèl susitraukimo deformaciju ir juos perskirstant tarp sluoksniu atitinkamai parinkus medžiagu (mūro ir betono) savybes ir sluoksnių skerspjūvio plotus.

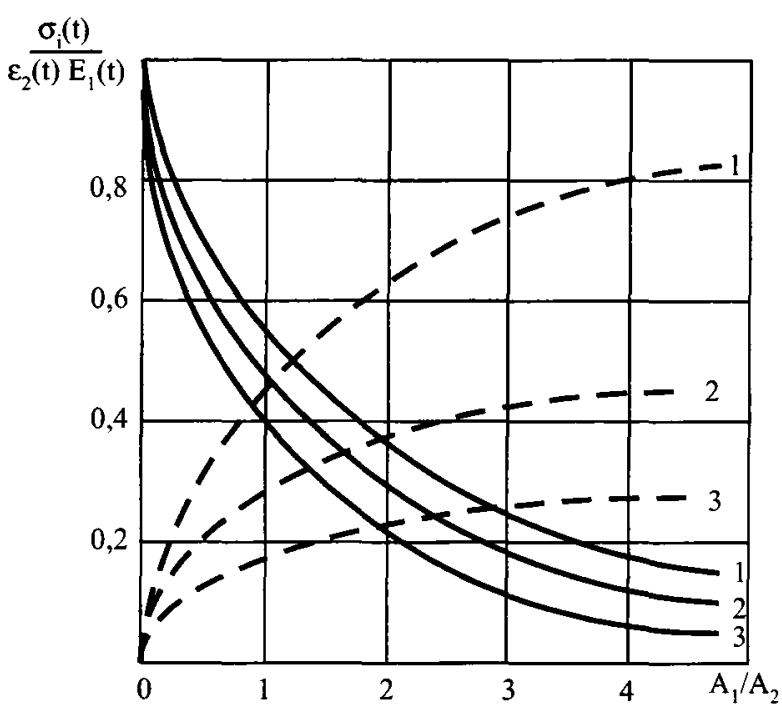

6 pav. Vidutiniu itempiu priklausomybè nuo sluoksniu skerspjūviu plotu $\left(A_{1} / A_{2}\right)$ santykiu ir medžiagu tamprumo moduliu $\left(E_{1}(t) / E_{2}(t)\right)$ santykių: gniuždymo itempiai; - - tempimo itempiai (skaičiai prie kreiviu reiškia $\left(E_{1}(t) / E_{2}(t)\right)$ santykiu dydi

Fig 6. Average stress on dependence the ratio of crosssectional areas of the layers $\left(A_{1} / A_{2}\right)$ and the modulus ratio $\left(E_{1}(t) / E_{2}(t)\right)$ : — compression stresses, - - tension stresses; number near lines correspond to $\left(E_{1}(t) / E_{2}(t)\right)$

\section{Išvados}

Gniuždomos kompleksinès mūrinès konstrukcijos priklauso sluoksniuotuju kompozitiniu konstrukciju grupei, tačiau jų skaičiavimas atliekamas supaprastintais metodais, neatsižvelgiant $\mathfrak{i}$ pagrindinị reikalavimą šio tipo konstrukcijai - sluoksnių deformacijų suderinamumą. Pastaraisiais metais pasirodo vis daugiau dirbiniu mūrui, tačiau nèra metodų mūro iš tokių dirbinių deformacinèms savybèms nustatyti, todèl sunku tiksliau ivertinti konstrukcijų sluoksnių skirtingu susitraukimo deformaciju itaka bendram jų itempimų ir deformacijų būviui.

Pasiūlyta metodika, kaip apskaičiuoti mūro iš ivvairiụ dirbiniu ir gelžbetonio susitraukimo deformacijas ir tamprumo modulius ir sumažinti ju skirtumą.

Gniuždymo ir tempimo itempiai, esant vienodam susitraukimui, priklauso nuo tụ sluoksniụ skerspjūvių plotų ir tamprumo modulių santykių. Pagal pasiūlytas formules galima apskaičiuoti vidutinius itempius esant skirtingam susitraukimui sluoksniuose ir jų kitimą pagal sluoksnių stori. Jų dydžius galima reguliuoti atitin- 
kamai parenkant sluoksnių tamprumų modulius ir skerspjūvių plotus.

Ittempimų ir deformaciju būvio ir ju persiskirstymo tarp sluoksnių ivertinimas leidžia vienodžiau išnaudoti jų laikomają galią, esant skirtingoms gniuždymo ribinèms deformacijoms.

\section{Literatūra}

1. A. W. Hendry. Structural Masonry. London: Macmillan Education Ltd. 1990. 282 p.

2. С. В. Поляков. Длительное сжатие кирпичной кладки Научное сообщение. Вып. 11. М.: Стройиздат, 1959. $181 \mathrm{c}$.

3. A. Rozenbliumas. Mūrinès konstrukcijos. Vilnius, 1956. $443 \mathrm{p}$.

4. G. Marčiukaitis, J. Valivonis. Mūro susitraukimo deformaciju ivertinimas, analizuojant pastatu vidiniu sienц supleišejimą // Statyba, VI t., Nr. 1. Vilnius: Technika, 2000 , p. $11-16$.

5. Строительные нормы и правила. Нормы проектирования. Каменные и армокаменные конструкции СниП II-22-81. М.: Стройиздат, 1983. 38 с.

6. Пособие по проектированию каменных и армокаменных конструкций (к СниП II-22-81). М.: Стройиздат, 1988. $149 \mathrm{c}$.

7. Eurocode 6. Design of Masonry Structures. Part 1-1: General Rules for Buildings. Rules for Reinforced and Unreinforced Masonry. Brussels, 1994. 210 p.

8. R. O. Hedstrom, A. Litvin, I. A. Hanson. Influence Mortar and Block Properties on Shrinkage Cracking of Masonry Walls. Portland Cement Association, Bulletin 0131, Skokie, Ilinois, 1968. 51 p.

9. J. O. Bryson, D. Watstein. Comparison of Four Different Methods of Determining Drying Shrinkage of Concrete Masonry Units // Journal of the American Concrete Institute, Vol 58, No 2, 1961, p. 163-184.

10. R. Gilbert. Time Effect in Concrete Structures. Amsterdam. Elsevier Science Publisher B.V., 1988. 284 p.

11. Concrete Structures Euro-Design Handbook. Edit. By Eibl J. Berlin, Erkstand Sohn, 1995. 754 p.

12. И. И. Улицкий. Теория и расчет железобетонных стержневых конструкций с учетом длительных процессов. Киев: Будивельник, 1967. 346 с.

13. С. В. Александровский. Расчет бетонных и железобетонных конструкций на температурные и влажные воздействия. М.: Стройиздат, 1973. 442 с.

14. Z. P. Bažant, J. K. Kim. Improved Prediction Model for Time-Dependent Deformations of Concrete // Materials and Structures. Part 1 - Shrinkage, Vol 24, 1991, p. 327 345 .

15. Г. Марчюкайтис. Исследование физико-механических свойств бетона и железобетона, пропитанных полиме- рами, и их учет при расчете конструкций. Дис. .. габил. д-ра. Вильнюс-Москва, 1979. 407 с.

16. Г. В. Лобанова. Теоретическое исследование зависимости ползучести и усадки бетона от изменения его влажностного состояния. Автореф. дис. ... канд. техн. наук. Ленинград, 1973. 21 с.

17. Eurocode 2 (EC2). Design of Concrete structures. Part 1: General Rules and Rules for Buildings. Brussels, Belgium, 1992. 458 p.

18. G. Marčiukaitis. Sluoksniuotuju statybiniu kompozitu valkšnumo parametru nustatymas // Statyba, IV t., Nr. 2. Vilnius: Technika, 1998, p. 101-108.

19. G. Marčiukaitis. Statybinių kompozitu kürimo ir savybiu prognozavimo principai. Vilnius: Technika, 1998. $134 \mathrm{p}$.

20. G. Marčiukaitis. Deformacinių savybiu itakos betono stiprumo išnaudojimui sluoksniuotame elemente jvertinimas // 4-osios tarptautinès konferencijos „Naujos statybinès medžiagos, konstrukcijos ir technologijos", ivykusios 1995 m. gegužès 10-13 d., straipsniai. II tomas. Vilnius: Technika, 1995, p. 73-78.

Iteikta 20010228

\section{SHRINKAGE INFLUENCE ON STRESS-STRAIN STATE OF COMPOSITE MASONRY MEMBERS}

\section{G. Marčiukaitis}

\section{Summary}

Composite masonry structures consists of various units (bricks or ceramic, concrete and other blocks) masonry and concrete or reinforced concrete layers. Analysis has shown that in most cases deformation properties of masonry, concrete and reinforced concrete are different. There is a big difference in modulus of elasticity and shrinkage deformations. Methods for determination of shrinkage and modulus of elasticity for different types of masonry and reinforced concrete have been presented. Analysis of distribution of stresses and deformations in layers has shown that for a given difference of shrinkage in layers the stresses of tension and compression in the layers depend on the cross-section area of these layers and the ratio of the modulus of elasticity. Formulas are given for calculation of these stresses.

Gediminas MARČIUKAITIS. Professor, Doctor Habil, Head of Dept of Reinforced Concrete and Masonry Structures. Vilnius Gediminas Technical University (VGTU), Sauletekio al. 11, LT-2040 Vilnius, Lithuania. E-mail: gelz@st.vtu.lt

PhD Kaunas Politechnical Institute (1963). Research visit to the University of Illinois (1969). Doctor Habil (1980) at Moscow Civil Engineering University, Professor (1982). Author and co-author of 5 monographs, 3 text-books and about 280 scientific articles. Research interests: mechanics of reinforced concrete, masonry and layered structures, new composite materials, investigation and renovation of buildings. 